\title{
Reassessing Dual Responsibility for International Crimes
}

\section{Reavaliando a Dupla Responsabilidade por Crimes Internacionais}

\author{
Beatrice I. Bonafè \\ Università di Roma - La Sapienza, Roma, Itália
}

\begin{abstract}
International Court of Justice in the case between Croatia and Serbia provides us with the opportunity to reassess the relationship between state and individual responsibility for international crimes. Although limited to the commission of acts of genocide, the judgment shows that the conceptual framework explaining such relationship is now well settled. However, the Court seems to reach solutions that at times are not entirely consistent with the premises of such conceptual scheme. The purpose of the following analysis is to test the general theoretical approach with respect to a number of issues dealt with by the Court in its recent decision.
\end{abstract}

Keywords: International Crimes. Individual and State Responsibility. Genocide Cases.
Resumo: a recente decisão da Corte Internacional de Justiça no caso entre Croácia e Sérvia nos oferece a oportunidade de reavaliar a relação entre responsabilidade individual e estatal por crimes internacionais. Embora limitada ao cometimento de atos de genocídio, a sentença demonstra que o quadro conceitual explicando tal relação é ora bem definido. Contudo, a Corte parece chegar a conclusões que por vezes não são completamente consistentes com as premissas de tal quadro conceitual. O objetivo da análise é testar a abordagem teórica geral em relação a alguns problemas lidados pela Corte em sua recente decisão.

Palavras-chave: Crimes Internacionais. Responsabilidade Individual e Estatal. Casos Genocídio.

\section{The General Approach Towards dual Responsibility}

The Court was asked to rule on Croatia's claim and Serbia's counter-claim both concerning the alleged commission of genocide by

Recebido em: 17/05/2016

Revisado em: 12/07/2016

Aprovado em: 18/07/2016 
the other party ${ }^{1}$. Eventually, the Court rejected both: it found evidence that material acts of genocide had been perpetrated, but was not provided with sufficient evidence that those acts had been committed with the required specific intent to destroy in whole or in part a particular group, i.e., genocidal intent. One of the central issues of the case regarded the relationship between state and individual responsibility for genocide under international law. Indeed, certain facts at issue before the Court had already formed the subject of proceedings before the International Criminal Tribunal for former Yugoslavia (ICTY). And the Court had to clarify 1) whether state responsibility could be assessed even though the individual criminal responsibility of its organs for the same conduct had not been previously established and 2) which probative value could be attributed to the decisions of the ICTY, since no accused before the Tribunal had been convicted with regard to the facts at issue before the Court.

As to the first question, the Court recalled what it had already observed in the 2007 decision on the genocide case between Bosnia and Serbia: "State responsibility can arise under the Convention for genocide and complicity, without an individual being convicted of the crime or an associated one" 2 . Therefore, a state can in principle be held responsible for genocide even if none of its organs has been convicted for genocide. In addition, the Court noted that: "State responsibility and individual criminal responsibility are governed by different legal régimes and pursue different aims. The former concerns the consequences of the breach by a State of the obligations imposed upon it by international law, whereas the latter is concerned with the responsibility of an individual [...] and the resultant sanctions to be imposed upon that person"3. The Court could not express more clearly the separation between the regime of state responsibility and the regime of individual criminal liability

\footnotetext{
${ }^{1}$ ICJ, Application of the Convention on the Prevention and Punishment of the Crime of Genocide (Croatia v. Serbia), Judgment, 3 February 2015 [hereafter: 2015 Genocide case], available on the Court's website (www.icj-cij.org).

${ }^{2}$ ICJ, Application of the Convention on the Prevention and Punishment of the Crime of Genocide (Bosnia and Herzegovina v. Serbia and Montenegro), Judgment [hereafter: 2007 Genocide case], I.C.J. Reports 2007, para. 182.
}

${ }^{3}$ ICJ, 2015 Genocide case, para. 129. 
for international crimes. In other words, different sets of secondary rules entail state and individual responsibility. As far as genocide is concerned, the Court explained that state responsibility would be established according to "the rules of general international law on the responsibility of States for internationally wrongful acts"4. But the same would undoubtedly apply to the establishment of state responsibility for other international crimes. On the other hand, individuals are convicted or acquitted by applying the secondary rules of international criminal $\mathrm{law}^{5}$. One of the clearest signs of this separation between the regimes of state and individual responsibility for international crimes is that there are different and independent bodies charged with enforcing obligations of states and obligations of individuals under international law. Thus, just as "it is not for the Court to determine the individual criminal responsibility for such acts", it is not for international criminal tribunals to determine state responsibility for international crimes ${ }^{7}$.

As to the second question, the Court clarified that the jurisprudence of international criminal courts and tribunals might nonetheless be taken into account in the establishment of state responsibility as far as the "constitutive elements" of the crime of genocide are concerned. In other words, the establishments of the ICTY were relevant as far as the violation of primary norms is concerned. The same case law was irrelevant in the application of the secondary norms of state responsibility. Indeed, the Court added that: "If it is established that genocide has been committed, the Court will then seek to determine the responsibility of the State, on the basis of the rules of general international law governing the responsibility of States for internationally wrongful acts" $"$. Accordingly, individual and state responsibility are separate regimes of responsibility but they are entailed by the breach of the same primary obligations.

${ }^{4}$ Ibid., para. 128.

${ }^{5}$ See for example ICTY, Prosecutor v. Krstic, IT-98-33-T, Trial Judgment, 2 August 2001, para. 2.

${ }^{6}$ ICJ, 2015 Genocide case, para. 129.

${ }^{7}$ This has been affirmed for example by the ICTY in Prosecutor v. Kunarac et al., IT-9623-T \& IT-96-23/1-T, Trial Judgment, 22 February 2001, para. 470.

${ }^{8}$ ICJ, 2015 Genocide case, para. 129. 
Other conceptual schemes can certainly be envisaged and have actually been put forward by international scholars 9 . However, the conceptual scheme adopted by the Court, according to which state and individual responsibility originate from the violation of the same primary rules but consist of different sets of secondary rules, seems to have gained wide support. It was already at the basis of the 2007 decision in the Bosnia v. Serbia case ${ }^{10}$; it is reflected in the works of the International Law Commission (ILC) ${ }^{11}$; it is reaffirmed in the Statute of the International Criminal Court (ICC) ${ }^{12}$; and has been expressed in similar terms by ad hoc tribunals ${ }^{13}$. It must be added that this conceptual scheme is not limited to the crime of genocide but is capable of explaining the relationship between the regimes of state and individual responsibility with respect to all "core crimes" prohibited under customary international

\footnotetext{
${ }^{9}$ At least two other approaches can be identified: an individual-oriented approach according to which international criminal law is fully independent from state responsibility as even the primary norms entailing state and individual responsibility are different; and a stateoriented approach according to which individual criminal responsibility is to be understood as nothing else but a consequence of the regime of state responsibility. For a detailed analysis, see B.I. Bonafé, The Relationship between State and Individual Responsibility for International Crimes, Leiden/Boston, Martinus Nijhoff, 2009, p. 43-68.

${ }^{10}$ ICJ, 2007 Genocide case, paras 163, 173 and 182.

${ }^{11}$ The ILC Articles on State Responsibility include a without prejudice clause - article 58 - according to which "These articles are without prejudice to any question of the individual responsibility under international law of any person acting on behalf of a State" (General Assembly resolution 56/83 of 12 December 2001). The ILC Draft Code of Crimes against the Peace and Security of Mankind include a similar clause - article 4 which reads: "The fact that the present Code provides for the responsibility of individuals for crimes against the peace and security of mankind is without prejudice to any question of the responsibility of States under international law".

${ }^{12}$ Article 25, paragraph 4, of the ICC Statute reads: "No provision in this Statute relating to individual criminal responsibility shall affect the responsibility of States under international law".

${ }^{13}$ See in particular ICTY, Prosecutor v. Furundzija, IT-95-17/1-T, Trial Judgment, 10 December 1998, para. 142 ("Under current international humanitarian law, in addition to individual criminal liability, State responsibility may ensue as a result of State officials engaging in torture or failing to prevent torture or to punish torturers. If carried out as an extensive practice of State officials, torture amounts to a serious breach on a widespread scale of an international obligation of essential importance for safeguarding the human being, thus constituting a particularly grave wrongful act generating State responsibility").
} 
law, namely, war crimes, crimes against humanity, genocide and the crime of aggression ${ }^{14}$.

As a consequence, while consistency should be ensured in the application of primary norms, the establishment of individual and state responsibility remain separate. With respect to the same facts, a state might be responsible while the individual perpetrator can be acquitted - and the other way around - according to the requirements of each responsibility regime and the actual possibility to prove them ${ }^{15}$.

In practice, however, one has to admit that it is not always easy to decide whether a certain norm is primary or secondary ${ }^{16}$ in character and this may not facilitate the application of the described conceptual scheme. On the other hand, international courts display a certain tendency to apply very similar standards in the establishment of both kinds of responsibility ${ }^{17}$. A closer look at the case law of the International Court of Justice reveals that state responsibility has only been established in connection with facts that had already entailed the individual criminal responsibility of their authors. Then the question is whether this practice puts into question the general conceptual scheme just described.

\footnotetext{
${ }^{14}$ Today it is no longer doubtful that those crimes entail not only state responsibility but also individual criminal responsibility. See in general A. Cassese, International Criminal Law, Oxford, Oxford University Press, 2003.

${ }^{15}$ See for example "Report of the International Commission of Inquiry on Darfur to the United Nations Secretary- General pursuant to Security Council Resolution 1564 of 18 September 2004", Geneva, 25 January 2005.

${ }^{16}$ The distinction between primary and secondary norms was proposed as a general criterion to codify the law of state responsibility by Special Rapporteur Ago in his "Second Report on State Responsibility”, Yearbook of the International Law Commission, 1970, vol. II, p. 179. See also J. Combacau and D. Alland, "Primary and Secondary Rules in the Law of State Responsibility: Categorising International Obligations", Netherlands Yearbook of International Law, 1985, pp. 81-109; J. Crawford, "First Report on State Responsibility", UN Doc. A/CN.4/490, paras. 12-18; P.-M. Dupuy, "A General Stocktaking of the Connections between the Multilateral Dimension of Obligations and Codification of the Law of Responsibility", European Journal of International Law, 2002, p. 1059. For a broader conception of secondary rules, see, H.L.A. Hart, The Concept of Law, Oxford, Clarendon Press, 1994, pp. 79-99 (originally published in 1961).

${ }^{17}$ See in that regard B.I. Bonafé, supra note 9, p. $71 \mathrm{ff}$.
} 


\section{The Overlap of Primary Norms}

In 2007 the Court recognised that "if a State is to be responsible because it has breached its obligation not to commit genocide, it must be shown that genocide as defined in the Convention has been committed"18, and the same approach is taken in 2015. Accordingly, for the Court the definition of genocide provided by article II of the Genocide Convention represents a primary norm whose violation entails state responsibility just as it entails individual criminal responsibility. This explains the relevance accorded to the case law of international criminal courts and tribunals not just in the establishment of facts but also in the interpretation of the primary rules to be applied when assessing that an international crime has been committed. This explains why the part of the Court's decision dedicated to the interpretation of the primary norm on the prohibition of genocide strongly relies on the case law of the ad hoc tribunals.

With respect to the "actus reus" of genocide, the Court carries out a detailed analysis of the various limbs of article II of the Genocide Convention in order to determine their meaning and scope. And the decision of the Court systematically refers to the case law of the ad hoc tribunals before reaching conclusions on the interpretation to be given to article II which are entirely consistent to the decisions already taken by those tribunals ${ }^{19}$.

A similar approach is taken with respect to the "mens rea" of genocide. This element of the definition of genocide was the object of specific analysis in the 2007 judgment - to which the recent decision refers - and the conclusion of the Court is that the dolus specialis required under article II of the Convention must be established in order for states to incur international responsibility for genocide ${ }^{20}$. Similarly, the Court upholds a definition of this element that corresponds to the one applied by international criminal tribunals.

\footnotetext{
${ }^{18}$ ICJ, 2007 Genocide case, para. 180.

${ }^{19}$ ICJ, 2015 Genocide case, paras 154-163.

${ }^{20}$ ICJ, 2007 Genocide case, para. $186 \mathrm{ff}$.
} 
This position of the Court has been criticised because it would have erroneously applied a typical requirement of the regime of individual criminal responsibility - the mens rea - to the regime of state responsibility where such secondary rule should not be applied. According to Gaeta,

[f]or the international responsibility of the state to arise, however, there would be no need to demonstrate that the state as such - or one or more of its officials - harboured a genocidal intent in the criminal sense. This is a requirement that only pertains to the criminal liability of individuals ${ }^{21}$.

Under international criminal law, the mens rea is a fundamental ingredient of individual responsibility, as the latter is grounded on the principle of personal culpability ${ }^{22}$. The accused cannot be convicted if he or she has not materially participated in the commission of the crime. International criminal law rejects the application of vicarious liability. But this is not enough. The psychological participation of the accused in the offence must be proved as well. There are various degrees of mens rea under international criminal law, but this fundamental requirement must always be established beyond reasonable doubt. The mens rea is a characterizing feature of the international regime of individual criminal responsibility - as it is under national criminal law - and is the expression of a general secondary rule that applies independently of the crime allegedly committed by the accused.

To a certain extent, a similar concern is expressed in the rules governing state responsibility. Indeed, states cannot be responsible for the conduct of private persons. This result is ensured through the application of a different set of secondary norms, namely, those concerning attribution. However, no state fault is required under the general regime of state responsibility. This does not exclude that certain primary norms provide for a state fault requirement. As the ILC clarified

${ }^{21}$ P. Gaeta, "On What Conditions Can a State Be Held Responsible for Genocide?", European Journal of International Law, 2007, p. 643.

${ }^{22}$ See in general A. Cassese, supra note 14, p. 159 ff. 
in the commentary on the Draft Articles on State Responsibility, "[a] related question is whether fault constitutes a necessary element of the internationally wrongful act of a State. This is certainly not the case if by 'fault' one under - stands the existence, for example, of an intention to harm. In the absence of any specific requirement of a mental element in terms of the primary obligation, it is only the act of a State that matters, independently of any intention"23.

Accordingly, the recognition that genocide requires the proof of a mens rea element in the establishment of both state and individual responsibility is not inconsistent with the general conceptual scheme described above. In principle, the mental element marks a clear distinction between the two regimes unless a primary norm requires this element to be established in order to find state responsibility.

Still, a certain distinction between the mens rea of the state and the mens rea of the individual charged with the same prohibited conduct amounting to an international crime can be maintained at least in principle. The purpose of the former requirement is to establish the psychological participation of a single person, while the latter aims at establishing the "mental" participation of a collective entity such as a state. This distinction may however be blurred in practice.

International criminal tribunals held that the mens rea should in principle be inferred from the personal conduct of the accused, i.e., words or deeds or a pattern of purposeful action, but they accepted that the general criminal context might play a role in that regard. For example, with respect to genocide, the International Criminal Tribunal for Rwanda (ICTR) admitted that "it is possible to deduce the genocidal intent inherent in a particular act charged from the general context of the perpetration of other culpable acts systematically directed against that same group, whether these acts were committed by the same offender or by others. Other factors, such as the scale of atrocities committed, their general nature, in a region or a country, or furthermore, the fact of deliberately and systematically targeting victims on account of their membership of a particular group, while excluding the members of

${ }^{23}$ Yearbook of the International Law Commission, 2001, vol. II(2), p. 36. 
other groups, can enable the Chamber to infer the genocidal intent of a particular act" $" 24$. As to the ICTY, it recognised that acts not amounting to genocide can be taken into account when establishing the genocidal intent of the accused ${ }^{25}$. Furthermore, it must be recalled that the genocidal intent need not be proved, and a lower standard of mens rea suffices, when the person convicted for genocide has been found guilty as an accomplice or under the doctrine of command responsibility. In other words, certain modes of liability do not require proof of genocidal intent as such ${ }^{26}$.

On the other hand, the International Court of Justice has considered that state "mens rea" need not be proved by showing that individual state organs harboured genocidal intent. State fault can be established indirectly by relying on a "pattern of conduct" pointing to the existence of genocidal intent ${ }^{27}$. In practice however the Court has never established state responsibility for genocide in the absence of a prior conviction of the responsible state organs, that is, in the absence of a judicial decision having already found that the genocidal intent could be attributed to state organs.

\section{The Separation of Secondary Norms}

The case law of the International Court of Justice clearly relies on the separation of the regimes of state and individual responsibility under international law. It suffices to recall how the Court reacted to the Tadic case in which the ICTY had ruled on the criteria for attributing individual conduct to a state and distanced itself from the "effective control" criterion applied by the Court in Nicaragua: "the ICTY was not called upon in the Tadic case, nor is it in general called upon, to rule on questions of State responsibility, since its jurisdiction is criminal and extends over persons only"28.

This separation entails two main consequences. The two regimes include different secondary rules, such as those governing attribution

\footnotetext{
${ }^{24}$ ICTR, Prosecutor v. Akayesu, ICTR-96-4-T, Trial Judgment, 2 September 1998, para. 523.

${ }^{25}$ ICTY, Prosecutor v. Krstic, IT-98-33-T, Trial Judgment, 2 August 2001, para. 580.

${ }^{26}$ For a more detailed analysis see B.I. Bonafé, supra note 9, p. $131 \mathrm{ff}$.

${ }^{27}$ ICJ, 2015 Genocide case, paras 139 and 148.

${ }^{28}$ ICJ, 2007 Genocide case, para. 403.
} 
or reparation. The two regimes are complementary in the sense that individual criminal responsibility is no substitute for state responsibility and the reparation of the victims of international crimes by the responsible state does not preclude the exercise of criminal jurisdiction over the offenders. As explained by the ILC,

[w] here crimes against international law are committed by State officials, it will often be the case that the State itself is responsible for the acts in question or for failure to prevent or punish them. In certain cases, in particular aggression, the State will by definition be involved. Even so, the question of individual responsibility is in principle distinct from the question of State responsibility. The State is not exempted from its own responsibility for internationally wrongful conduct by the prosecution and punishment of the State officials who carried it out. Nor may those officials hide behind the State in respect of their own responsibility for conduct of theirs which is contrary to rules of international law which are applicable to them ${ }^{29}$.

However, the Court is not always consistent with this conceptual scheme. Two examples with respect to the crime of genocide are provided by the recent decision settling the dispute between Croatia and Serbia.

\subsection{Responsibility for Isolated acts of Genocide?}

Under the general regime of state responsibility, "the conduct of any State organ shall be considered an act of that State under international law" ${ }^{30}$. No matter if the breach is isolated or state organs commit repeated breaches, the state would be responsible under international law. As far as genocide is concerned, in addition to the attribution of the material breach state responsibility requires the establishment of state fault. This may be a difficult element to prove but two main possibilities are available: either proof is given of the mental element of those state organs who have

\footnotetext{
${ }^{29}$ ILC Commentary on article 58 of the Draft Articles on State Responsibility, supra note 22 , p. 142, para. 3. A similar stand is taken by the ILC in the commentary on article 4 of the Draft Code of the Crimes against Peace and Security of Mankind, Yearbook of the International Law Commission, 1996, vol. II(2), p. 24.

${ }^{30}$ Article 4 of the ILC Articles on State Responsibility (emphasis added).
} 
committed the wrongful act, or state fault is established at a more general level by relying on a pattern of conduct pointing to the existence of a certain state intention ${ }^{31}$.

As already noted, the Court has made it clear that no prior conviction of the responsible state organ is required to hold a state responsible for an international crime. Therefore, in principle the establishment of state responsibility is completely independent from the issue of individual criminal responsibility ${ }^{32}$. However, the 2015 decision of the Court does not seem entirely consistent with such premises.

Being "fully convinced that, in various localities in Eastern Slavonia, Western Slavonia, Banovina/Banija, Kordun, Lika and Dalmatia, the JNA and Serb forces perpetrated against members of the protected group acts falling within subparagraphs (a) and (b) of Article II of the Convention, and that the actus reus of genocide has been established"33, the Court moved to the assessment of the genocidal intent having inspired those acts and concluded, as mentioned, that Croatia had not established that those acts were committed with the specific intent required for them to be characterized as acts of genocide ${ }^{34}$. The main reason for this was that "the acts committed by the JNA and Serb forces essentially had the effect of making the Croat population flee the territories concerned. It was not a question of systematically destroying that population, but of forcing it to leave the areas controlled by these armed forces" 35 . In other words, the Court confirmed the position already adopted by the ICTY in a number of judgments that the 2015 decision frequently mentions and in which the ICTY was not asked to establish whether genocide had been committed $^{36}$. So it remains obscure what has prevented the Court from asking whether those acts could also have pointed to the existence of a genocidal intent. The sole contribution of

${ }^{31}$ See B.I. Bonafé, supra note 9, p. $120 \mathrm{ff}$.

32 The question is not directly relevant here but the same is true for individual criminal responsibility with the partial exception of the crime of aggression.

${ }^{33}$ ICJ, 2015 Genocide case, para. 401.

${ }^{34}$ Ibid., paras 402-440.

${ }^{35}$ Ibid., para. 435.

${ }^{36}$ The same can be said of the conclusion concerning Serbia's counter-claim. See para. 506 . 
the Court was to consider that in any case 12.500 Croat deaths was a "number of victims [...] small in relation to the size of the targeted part of the group" 37 . Inevitably, one wonders why the Court has not carried out an independent assessment. The fact that the ICTY had not convicted any accused for genocide and had not even charged any individual with genocide $^{38}$ is not a sufficient reason for the Court to refrain from carrying out an independent assessment of state responsibility.

What is even more curious is the way in which the Court easily dismissed evidence that seemed to point to the existence of a genocidal intent on the part of Serb paramilitary forces. Paragraph 438 reads:

Croatia points to activities of Serb paramilitaries as evidence of the dolus specialis. In particular, it relies upon a videotape of Zeljko Raznatovic or 'Arkan', leader of a Serb paramilitary group known as the 'Serbian Volunteer Guard' or 'Arkan's Tigers', made during the siege of Vukovar on 1 November 1991, showing him instructing his forces to take care not to kill Serbs and saying that since Serbs were in the basements of buildings and the Croats were upstairs, rocket launchers should be used to 'neutralize the first floor'. Even if Arkan's actions were attributable to Serbia, this speech appears to be but one isolated phase in the very lengthy siege of Vukovar, a siege in which, as the Court has already found (see paragraphs 218-219, 301 and 305 above), the degree of violence used by attacking forces was excessive, and during which grave suffering was undoubtedly caused to the civilian population as Serbia acknowledged at least to some extent. It is difficult to infer anything from one isolated instance. Croatia also relies upon the report of a JNA security officer, dated 13 October 1991, which stated that Arkan's troops were 'committing uncontrolled genocide and various acts of terrorism' in the greater area of Vukovar. The Serbian Assistant Minister of Defence was informed of the report. Yet taking the report as a whole, no justification or examples are given to support the use of the word 'genocide'.

${ }^{37}$ Ibid., para. 437. The Court adopted a similar view in considering Serbia's counterclaim. See para. 512 .

${ }^{38}$ Ibid., para. 440. 
Certainly, one is aware of the fact that it can be extremely difficult to prove that isolated acts of genocide have been carried out with the required dolus specialis ${ }^{39}$. However, this possibility is not ruled out by the definition of genocide. If it were possible to establish that state organs had committed isolated acts of genocide with the required genocidal intent, why would the state not be responsible? We can agree with the Court when it notes: "it is difficult to establish such [genocidal] intent on the basis of isolated acts" ${ }^{40}$. But this does not prevent the Court from at least trying. In other words, the Court could have carried out a more detailed analysis of the evidence before it and should have explained the reasons why it concluded that 'Arkan's Tigers' had not acted with the required mens rea.

\subsection{Different Standards of Proof?}

The issue of the standard of proof applicable to the establishment of state responsibility for genocide had been crucial in 2007 when the Court adopted its judgment in the genocide case between Bosnia and Serbia. That decision had been criticised $^{41}$ because it referred to a number of different standards of proof and among them the "beyond any reasonable doubt" standard that is typically applied in international criminal proceedings ${ }^{42}$. This is a very high standard and finds no precedent in the Court's case law dealing with state responsibility.

The decision rendered in the Croatia v. Serbia case simply refers to the 2007 decision for the definition of the applicable standard of proof, although it makes an attempt to use a more uniform terminology. Claims of genocide must be proved by evidence that is "fully conclusive" and the Court must be "fully convinced" that genocide has been committed ${ }^{43}$. It is

\footnotetext{
${ }^{39}$ See in particular ICTY, Prosecutor v. Jelisic, IT-95-10-T, Trial Judgment, 14 December 1999, paras 100-101.

${ }^{40}$ ICJ, 2015 Genocide case, para. 139.

${ }^{41}$ See for example A. Gattini, "Evidentiary Issues in the ICJ's Genocide Judgment", Journal of International Criminal Justice, 2007, p. 889.

${ }^{42}$ ICJ, 2007 Genocide case, in particular paras 312, 314, and 422.

${ }^{43}$ ICJ, 2015 Genocide case, para. 178.
} 
according to this standard of proof that the Court reaches the conclusion that material acts falling within article II of the Genocide Convention had been committed ${ }^{44}$.

Apparently, the Court has adopted a different standard of proof as far as the dolus specialis is concerned. In this case, the existence of the genocidal intent must be "the only inference that could reasonably be drawn from the acts in question" 45 . It must be noted that the decision carefully avoids any reference to the "beyond any reasonable doubt" standard. However, when establishing the mens rea of genocide it insists on two elements: the fact that the inference must be the "only" inference possible and the "reasonableness" of that inference. With respect to Croatia's claim, the Court could not conclude that the "only reasonable inference" that could be drawn from the pattern of Serb acts constituting the actus reus of genocide was the intent to destroy in whole or in part the Croat group ${ }^{46}$. With respect to Serbia's counter-claim, the Court was unable to conclude that the pattern of conduct on the part of the Croatian authorities could "only reasonably" be understood as reflecting a genocidal intent.

It seems that in the end the standard of proof applied by the Court is nothing else but the "beyond reasonable doubt" that is typical of international criminal law. The judgment itself admits: "the criterion applied by the ICTY Trial Chamber in the Judgment in the Tolimir case is in substance identical with that laid down by the Court in its 2007 Judgment"47. In addition, the opinions of some judges confirm that the Court should apply the same standard of proof as applied by international criminal tribunals ${ }^{48}$. However, this conclusion is not entirely convincing.

From the perspective of the relationship between state and individual responsibility, one may argue that rules on the standard of

\footnotetext{
${ }^{44}$ Ibid., paras 401 and 499.

${ }^{45}$ Ibid., paras 148 and 417.

${ }^{46}$ Ibid., para. 440.

${ }^{47}$ Ibid., para. 148.

${ }^{48}$ ICJ, 2015 Genocide case, Dissenting Opinion of Judge Cançado Trindade, para. 467, and Separate Opinion of Judge Keith, paras 3-4.
} 
proof are secondary norms and, accordingly, the standards of international criminal law are not necessarily applicable in the establishment of state responsibility, quite the opposite ${ }^{49}$.

The second reason seems more compelling. Even leaving aside the ambiguity relating to the application of different standards of proof to the establishment of the actus reus of genocide ("fully conclusive" evidence) and the mens rea of genocide ("the only reasonable inference"), the position of the Court is problematic because it does not justify the application in the framework of state responsibility of such a high standard of proof as is applied in the establishment of individual criminal responsibility. Assuming that the regime of state responsibility is not criminal in character ${ }^{50}$, it is difficult to understand why the application of this regime should rely on a standard of proof that is ultimately premised on the presumption of innocence of the accused. The "beyond any reasonable doubt" standard is particularly demanding precisely because it is meant to counterbalance the serious consequences attached to individual criminal responsibility. The function and nature of state responsibility do not seem to require a similar guarantee that could end up in unduly restricting the application of the regime of state responsibility for international crimes.

The Court seems to justify the application of a higher standard of proof with the gravity of the allegations made in the proceedings. ${ }^{51}$ This is problematic for a number of reasons. First, this justification is provided with respect to the "fully conclusive" standard only. Nowhere in the

49 This is not to deny the difficulty in identifying the primary or secondary character of certain international rules and the fact that certain standards of proof pertain to the application of primary norms and others to the application of secondary norms. However, one should not loose sight of the function of standards of proof and the connection with the aim pursued by the responsibility regime in which they apply.

${ }^{50}$ ILC Commentary on article 12 of the Draft Articles on State Responsibility, supra note 22, p. 55, para. 5. A previous version of the Draft Articles included a provision on "International crimes of states" (article 19). But even in that regard the ILC made it clear that it did not intend to establish a criminal responsibility of states. See Yearbook of the International Law Commission, 1976, vol. II(2), para. 59.

${ }^{51}$ ICJ, 2015 Genocide case, para. 178. See also ICJ, 2007 Genocide case, para. 209. 
judgment does the Court provide a similar justification with respect to the "only reasonable inference" standard.

Second, the Court refers to the merits decision in the Corfu Channel case where it had observed that

[...] [t]he statements attributed by the witness Kovacic to third parties, of which the Court has received no personal and direct confirmation, can be regarded only as allegations falling short of conclusive evidence. A charge of such exceptional gravity against a State would require a degree of certainty that has not been reached here ${ }^{52}$.

It must be recalled however that in that decision the affirmation of the Court had no general scope; the Court was referring to statements of third parties; and no clear standard of proof was set out with respect to "charges of exceptional gravity". If the affirmation of the Court were to be generalised, it would only imply that "conclusive" evidence is required for serious allegations. The conclusion according to which "fully" conclusive evidence would be required in such circumstances is entirely attributable to the 2007 genocide decision.

Third, the interpretation of the Corfu Channel case that has just been criticised seems to be the only basis for relying on a "fully conclusive" or "only reasonable inference" standards. One of the members of the Court suggested that "it is a well-settled principle of law that the graver the offence alleged, the higher the standard of proof required for said offence to be established in a court of law"53. However, when one looks at the case law of other international courts and tribunals one must recognise that different approaches have been adopted. There are indeed cases where the seriousness of the charges has been taken into account ${ }^{54}$. But there are also cases in which it was held that the gravity of the charges

\footnotetext{
${ }^{52}$ ICJ, Corfu Channel case, Judgment of April 9 $9^{\text {th }}$, 1949, I.C.J. Reports 1949, p. 17. ${ }^{53}$ ICJ, 2015 Genocide case, Separate Opinion of Judge Bhandari, para. 2.

${ }^{54}$ Inter-American Court of Human Rights, Velásquez Rodríguez, Judgment, 29 July 1988, para. 129 .
} 
does not change the international rules to be applied in order to establish state responsibility ${ }^{55}$.

Finally, the Court held in 2007 and confirmed in 2015 that a higher standard of proof "applies to the proof of attribution for such acts [of genocide]" ${ }^{\prime 56}$. Unfortunately, no specific reason is provided to justify such a conclusion that may reveal extremely problematic. In general, it is difficult to understand why this standard of proof should be relied upon in the application of secondary rules ${ }^{57}$. The Court itself recognised, although in a different framework, that rules on attribution are secondary rules ${ }^{58}$. Most importantly, it is unclear what does the Court mean when it says that the application of rules on attribution, think for example of effective control, requires a standard of proof that varies according to the gravity of the allegation. Inevitably, the risk is that the standard of proof would have an impact on the content of the rule concerning attribution and that attribution to the state would vary according to the gravity of the wrongful act.

\section{Conclusion}

The development of a general conceptual scheme by the Court has proved essential to appraise the relationship between state and individual responsibility and to ensure their complementarity. However, it remains a "conceptual scheme" and what counts is that the Court applies it in a consistent manner. Unfortunately this is not always the case. The case law examined does not seem to put into question the described conceptual scheme. The analysis of the mens rea requirement of genocide provides a good example in that regard. Nonetheless, the recent case law of the Court on the crime of genocide raises concern because it tends to blur the separation between two regimes of responsibility. In practice, state

\footnotetext{
${ }^{55}$ ICJ, 2015 Genocide case, Separate Opinion of Judge Gaja, para. 4, referring to the award of the Eritrea Ethiopia Claims Commission.

${ }^{56}$ ICJ, 2015 Genocide case, para. 178. See also ICJ, 2007 Genocide case, para. 209.

57 See in this respect M. Milanovic, "State Responsibility for Genocide", European Journal of International Law, 2006, p. 597.

${ }^{58}$ ICJ, 2015 Genocide case, para. 104.
} 
responsibility appears more dependent on the establishment of individual responsibility than it should be. In particular, state responsibility should not be confined to the safe area where individual responsibility has already been established. The risk is that the state would evade its responsibility on such crucial issues as the commission of international crimes.

Beatrice I. Bonafè é professora de Direito Internacional na Università di Roma - La Sapienza.

E-mail: beatrice.bonafe@uniroma1.it.

Endereço profissional: Piazzale Aldo Moro, 5, 00185 Roma, Itália. 